\section{脸波を検出して言葉に変換する 「意思伝達マシン」を開発!}

テレパシーが使えたら……相手に自分の意思を伝えるのが難しい重度の神経疾患 患者やその家族にとって、それはSF の話ではなく、切実で現実的な願いだ。これに 近い技術が、長谷川良平博士らによって開発された。患者の脳波の变化を検出する ことで、「水を飲みたい」といった意思を、人工の音声で伝えることができるという。
Nature ダイジェスト：ブレイン -マシンインターフェイス (BMI) とは、 どのようなものなのですか。

長谷川：「脳と機械をつなぐ手段とな る技術」を指す総称です。コンピュー ターを介することが多いので、「ブレ イン -コンピューターインターフェー ス $(\mathrm{BCI})\lrcorner$ とばれることもあります。 BMI には、脳内に電極を埋める侵襲的 BMI と、頭皮を通して脳波などを測定 する非侵襲的 BMI があります。

侵襲的 BMI の古い例としては、1960 年代に行われたラットを使った自己報酬 刺激の実験システムなどがあります。こ
れは、ラットの快楽中枢に電極を埋め込 み、ラットがレバーを押すと、そこに電 流が流れて快楽が得られるようにしたも のです。その後、サルの脳活動を記録し てロボットアームを制御する技術の開発 が盛んになりました。

ヒトを対象としたものでは、脳に電極 を埋めてパーキンソン病を治療する「脳 深部刺激治療」なども侵襲的 BMI の一 種といえます。このように、BMI は、 事故や疾病によって低下した脳や身体の 機能を補償することで、患者さんたちの 「生活の質 $(\mathrm{QOL}) 」 を$ 向上させる新技 術となると期待されています。
(3)効率的な意思伝達アプリケーション

「階層的メッセージ
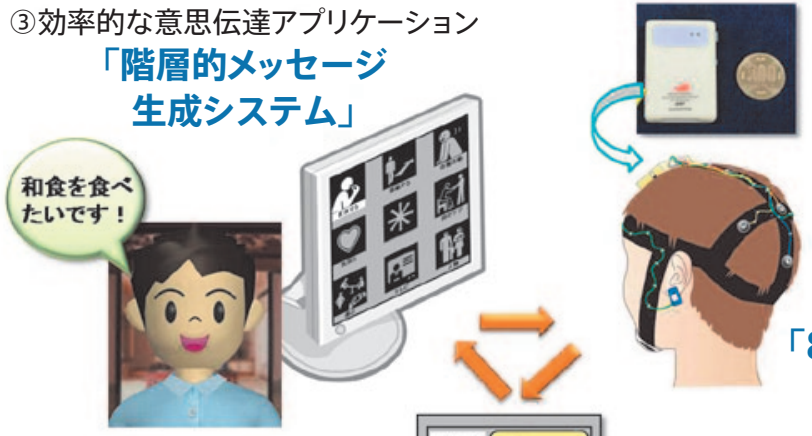

(1)モバイル脸波計

「8チャンネル超小型 無線脳波計」

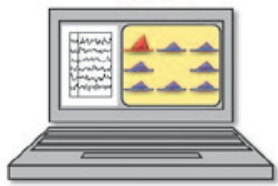

(2)高速·高精度脳内意志解読アルゴリズム 「仮想意志決定関数」

図 1 ニューロコミュニケーターの概念図。

患者さんの意思伝達マシンは、3つの要素を結ぶネットワークで構成されている。視覚刺激 を与えるのが「(3)階層的メッセージ生成システム」。これを見て決定された患者さんの意思は、 脳波の変化となり、ヘッドキャップに取り付けた 8 つのセンサー「1 8 チャンネル超小型無線 脳波計」で捕らえられる。この信号は、無線で解読のためのコンピューターに送られ、「(2)仮 想意思決定関数」で判断される。するとその結果が人工の音声に変換され、患者さんが意志 を伝えたい相手に送られる。
帚谷川别良苹

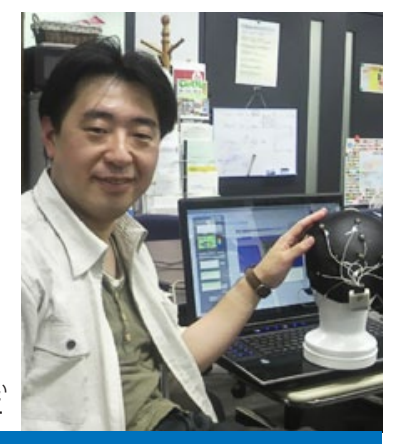

\section{脳の基礎研究から応用へ}

ーBMI に興味をもたれたきっかけは？ 産業技術総合研究所に赴任するまでは、 ヒトの高次脳機能の仕組みを明らかにす るために、霊長類を対象とした神経生理 学的な実験を続けていました。例えば、 サルが「脳トレゲーム」のような行動課 題を行っているときの脳活動を調べ、特 定の運動をしようと意思決定する際にの み活動するようなニューロンがないか、 探したりしていました。

ちょうど私が留学した 1998 年ごろか ら、米国で BMI 研究が活発になりまし た。その雾囲気を間近で感じ、それまで 自分が進めてきた「脳を理解するための 研究」の成果が、BMI 開発に応用でき るのではないかと考え、自分なりに実用 的な BMI を作る研究を始めることにし ました。

まず、動物が「二者択一の意思決定」 を行っている最中の脳活動を記録し、そ れを単一の試行単位で解読する手法を模 索し始めました。単一試行での解析は才 フラインで行いましたが、BMI で重要 なリアルタイムでの解析にも応用可能だ と考えました。

このような研究を進めて国内外で成 果を発表していくうちに、脳科学だけで なく、さまざまな研究分野の方々や新 聞・雑誌などのメディアにも興味をもつ ていただけるようになりました。それと ともに、疾患などによって自らの意思の 表出が困難になった方々の現状を耳に する機会も増え、単に脳内意思を解読す るだけでなく、解読した意思に基づいて 
外部機器を実際に動かしてみることの 必要性を痛感するようになりました。そ のような中で、研究室にこもつてばかり ではユーザーのニーズとかけ離れた技 術開発になってしまうとも考え、現在で は、基礎的研究から実用化に至るまで、 さまざまな段階の研究開発に同時に取 り組んでいます。

ニューロコミュニケーター（意思 伝達マシン) は、どのようにして脳内の 意思を読み取るのでしょう？

今回開発したニューロコミュニケー ター（図 1 ) は、携帯電話の半分以下の 大きさの「超小型無線脳波計」、患者さ んの脳波をとらえる「ヘッドキャップ」、 「コンピューターの端末」などが連動し て機能します。ヘッドキャップに取り付 けられた 8 か所のセンサーで、頭頂部 を中心にした脳波を検出・増幅し、それ を無線によって近くの制御用パソコン に送信します。利用に当たっては、患者 さんにコンピューターの画面を通して 視覚的な刺激を与え、個々の刺激に対す る患者さんの脳波の変化を読み取るこ とで、「患者さんの意思」としていち早 く検出します。

例えば、端末の画面に「りんご」、「み かん」「いちご」の 3 種類の果物を示 した図形が選択肢として提示されてい て、そのうちの1つを脳波によって選 んでもらう実験を想定してみましょう。 被験者には、事前にどの果物を選びたい のかを頭の中で決めておいてもらいま す。実験が開始すると、各図形が順次フ ラッシュします。被験者が選びたい図形 に視線を合わせるだけで、ターゲットが フラッシュした瞬間に増強される脳波の 成分 (P300) が検出されます。

ただし、P300 の出やすさや、よく出 る電極位置、出るタイミングなどには個 人差があるので、15 分ほどかけて予備 実験を行い、各個人に合わせたP300 の 出現パターンをコンピューターに学習さ せておきます。実験では、統計的手法を 用いて、それぞれの果物に対する P300
の反応の有無を判別し、選んだ図柄を計 算で導出します。

よく「候補の数だけ脳波のパターンが 違うのですか」という質問を受けますが、 実際には、各候補それぞれに「ターゲッ トであるかないか」の二者択一の解析を 行っているので、そのようなことはあり ません。被験者の慣れや電極の状態にも 左右されますが、1 時間ほど調整すれば、 多くの被験者で 90 パーセント以上の成 績を発揮できます。

\section{意思疎通の支援ツール}

——どのような患者さんに使えるので しょうか?

ある程度の視力があり、かつ脳波が記録 可能であれば使えます。眼球運動やまば たきを思うようにできない患者さん、耳 が聞こえない患者さんなどでも大丈夫で す。開発に当たって想定したのは、ALS (筋萎縮性側索硬化症)、脊䯣小脳変性症、 パーキンソン病などの神経系の難病が進 み、家族との意思疎通が難しくなった患 者さんですが、このような病気のご家族 だけでなく、自閉症や脳性麻痺のお子さ んをおもちの方からもたくさんの問い合 わせをいただいています。

試作機では、8つの選択肢からなる画 面を階層的に 3 画面用意し、最大 512 種類（8の 3 乗）の組み合わせメッセー ジの作成を可能にしました。ユーザーの 生活や赀好に合わせてカスタマイズして いただけば、日常生活には足りるのでは ないかと思っています。

\section{長谷川 良平}

\section{AUTTHOR PROAFIILE} ジー研究グループ長。1997 年、京都大学大学院理学研究科修了 (理学博士)。前頭連合 野における意思決定の脳内機構を研究した。1998 年、日本学術振興会海外特別研究員 として米国立衛生研究所に留学。2002 年、ノースウェスタン大学に赴任し、サルの上 丘ニューロン活動を利用した侵襲的 BMI 開発の研究を開始した。2004 年、産総研脳神 経情報研究部門（現ヒューマンライフテクノロジー研究部門）に着任。研究員、主任研 究員を経て現在、ニューロテクノロジー研究グループ長。サルやラットを対象に、高次 脳機能の解明とその BMI 応用に関する研究を進めてきたが、最近は、ヒトを対象にした 脳波および直感的インターフェースの開発にも取り組んでいる。 